\title{
KOLOKWIUM HABILITACYJNE DR. ALEKSANDRA STĘPKOWSKIEGO
}

W dniu 14 listopada 2011 r. na Wydziale Prawa Uniwersytetu Warszawskiego odbyło się kolokwium habilitacyjne dr. Aleksandra Stępkowskiego, adiunkta w Katedrze Historii Doktryn Politycznych i Prawnych.

Podstawą przewodu była rozprawa Zasada proporcjonalności w europejskiej kulturze prawnej. Sadowa kontrola wladzy dyskrecjonalnej w nowoczesnej Europie. Recenzentami pracy byli: prof. dr hab. Małgorzata Jaśkowska (Uniwersytet im. Kardynała Stefana Wyszyńskiego), prof. dr hab. Maria Zmierczak (Uniwersytet im. Adama Mickiewicza), prof. dr hab. Janusz Trzciński (Uniwersytet Wrocławski) oraz prof. dr hab. Eugeniusz Zwierzchowski (Uniwersytet Śląski).

Po zapoznaniu się z opiniami recenzentów i udzieleniu odpowiedzi na pytania przez habilitanta, Rada Wydziału postanowiła przyjąć kolokwium i nadać dr. Aleksandrowi Stępkowskiemu stopień naukowy doktora habilitowanego nauk prawnych.

KRZYSZTOF KOŹMIŃSKI (Warszawa)

\section{KOLOKWIUM HABILITACYJNE DR ANNY MACHNIKOWSKIEJ}

W dniu 28 listopada 2011 r. na Wydziale Prawa i Administracji Uniwersytetu Gdańskiego odbyło się kolokwium habilitacyjne dr Anny Machnikowskiej, adiunkta w Katedrze Historii Państwa i Prawa Polskiego Uniwersytetu Gdańskiego. Podstawą kolokwium habilitacyjnego była monografia zatytułowana Prawo wlasności w Polsce w latach 1944-1981. Funkcję recenzentów pełnili: prof. zw. dr hab. Marian Kallas (Wyższa Szkoła Finansów i Zarządzania w Warszawie), prof. zw. dr hab. Adam Lityński (Uniwersytet Śląski w Katowicach), prof. zw. dr hab. Andrzej Sylwestrzak (Uniwersytet Gdański) oraz prof. zw. dr hab. Bronisław Ziemianin (Uniwersytet Szczeciński). Wzięli oni także udział w posiedzeniu Rady Wydziału.

Po przeprowadzeniu kolokwium oraz wysłuchaniu wykładu habilitacyjnego zatytułowanego Prawo wlasności $w$ doktrynach politycznych i prawnych w XX wieku. Rada Wydziału Prawa i Administracji Uniwersytetu Gdańskiego jednogłośnie nadała dr Annie Machnikowskiej stopień naukowy doktora habilitowanego nauk prawnych.

JACEK WAEDOCH (Gdańsk)

\section{KOLOKWIUM HABILITACYJNE DR. LECHA MAŻEWSKIEGO}

W dniu 28 listopada 2011 r. przed Radą Wydziału Prawa i Administracji odbyło się kolokwium habilitacyjne dr. Lecha Mażewskiego, adiunkta w Katedrze Historii Państwa i Prawa Uniwersytetu Warmińsko-Mazurskiego w Olsztynie. Przedstawił on rozprawę habilitacyjną na podstawie monografii zatytułowanej Dluga dekada lat siedemdziesiatych (1968-1981). Rola nowelizacji z 10 lutego 1976 r. Konstytucji PRL z 22 lipca 1952 r. w ewolucji ustroju PRL na tle konstytucji europejskich państw socjalistycznych. Obowiązki recenzentów w przewodzie 
habilitacyjnym pełnili: prof. zw. dr hab. Andrzej Bałaban (Uniwersytet Szczeciński), prof. zw. dr hab. Marian Kallas (Wyższa Szkoła Finansów i Zarządzania w Warszawie), prof. zw. dr hab. Ryszard Laszewski (Uniwersytet Mikołaja Kopernika), prof. zw. dr hab. Dariusz Szpoper (Uniwersytet Gdański).

Po przeprowadzeniu kolokwium habilitacyjnego wysłuchano wykładu zatytułowanego Uprawnienia nadzwyczajne Glowy Państwa w Rzeczypospolitej Polskiej w latach 1918-1939. Następnie Rada Wydziału w głosowaniu tajnym podjęła uchwałe o nadaniu dr. Lechowi Mażewskiemu stopnia naukowego doktora habilitowanego nauk prawnych.

JACEK WAŁDOCH (Gdańsk) 